This is the author's final, peer-reviewed manuscript as accepted for publication. The publisher-formatted version may be available through the publisher's web site or your institution's library.

\title{
Ozonation as an alternative to chlorination for soft wheat flours
}

Sasivimon Chittrakorn, Dru Earls, Finlay MacRitchie

\section{How to cite this manuscript}

If you make reference to this version of the manuscript, use the following information:

Chittrakorn, S., Earls, D., \& MacRitchie, F. (2014). Ozonation as an alternative to chlorination for soft wheat flours. Retrieved from http://krex.ksu.edu

\section{Published Version Information}

Citation: Chittrakorn, S., Earls, D., \& MacRitchie, F. (2014). Ozonation as an alternative to chlorination for soft wheat flours. Journal of Cereal Science, 60(1), 217-221.

Copyright: (c) 2014 Elsevier Ltd.

Digital Object Identifier (DOI): doi:10.1016/j.jcs.2014.02.013

Publisher's Link: http://www.sciencedirect.com/science/article/pii/S0733521014000745

This item was retrieved from the K-State Research Exchange (K-REx), the institutional repository of Kansas State University. K-REx is available at http://krex.ksu.edu 


\section{Ozonation as an alternative to chlorination for soft wheat}

\section{flours $^{\text {मे }}$}

Sasivimon Chittrakorn ${ }^{\mathrm{a}, \mathrm{b}^{*}}$ Dru Earls $^{\mathrm{a}}$, Finlay MacRitchie ${ }^{\mathrm{a}}$

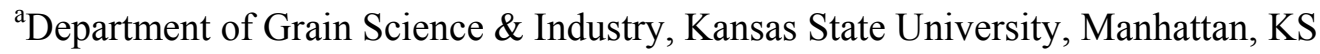

66506

${ }^{\mathrm{b}}$ Department of Agro Industry, Naresuan University, Phitsanulok, Thailand 65000

Highlights

- Ozonation of flours increased high ratio cake volumes

- There is an optimum ozonation treatment time

- Ozonation is a viable alternative to chlorination

- Ozonation affects flour lipids and proteins

Keywords

Ozonation, chlorination, cake volume, lipids

Contribution No. 10-379-J from the Kansas Agricultural Experiment Station.

* Corresponding author. Tel.: 66-55-962735; fax: 66-55-962703

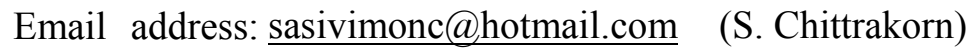




\section{ABSTRACT}

High ratio cakes made from ozonated flour attained volumes and other quality characteristics comparable to those from chlorinated flours at 36 min ozonation time.

Ozone thus appears to be a viable and more environmentally acceptable alternative to chlorine. Extraction of lipids from flour caused deterioration of cake quality which was not restored by ozonation indicating that lipids were involved in the improving effects of ozonation. Oxidation by ozone led to higher molecular weights of polymeric proteins.

\section{Introduction}

Chlorination of soft wheat flour has been used since the 1930s (Gough et al., 1978) to make them suitable for manufacture of high ratio cakes; i.e. cakes that use high proportions of shortening and sugar. Chlorine treatment has two main beneficial effects on flours. It prevents collapse of cakes after removal from the oven, giving rise to higher volumes, and acts as a bleaching agent to produce a whiter colour of the product. The chemistry of the effects of chlorine has not been clearly explained although studies have implicated its influence on gluten, prime starch (Sollars and Rubenthaler, 1971) and lipids in flour (Kissell and Yamazaki, 1979; Clements and Donelson, 1982).

Chlorination of flour is usually carried out in flour mills and, as chlorine is a poisonous gas, this has raised safety issues. Also, the use of such chemicals in food processing is of public concern (Thomasson et al. (1995). As a result, alternatives to chlorination have been sought (Donelson et al., 2000). For example, heat treatment has been used to reduce shrinkage of cake during baking and increase cake volume, 
effects similar to those of chlorination (Russo and Doe, 1970; Thomasson et al., 1995).

Ozone is a strong oxidizing agent similar to chlorine. It does not have the poisonous properties of chlorine, however, ozone is reported to be an effective alternative to conventional fumigants against a range of pests, micro-organisms and mycotoxins (Tiwari et al., 2001). When used for tempering of wheat grain prior to milling, it has been shown to reduce the required energy for milling (Desvignes et al., 2008). When flour was treated with ozone, its dough gave higher alveograph force and tenacity and lower extensibility (Violleau et al., 2012). In a study of breadmaking, flour treated with ozone gave larger specific bread volume and better crumb characteristics, suggesting that ozone could be a viable alternative to potassium bromate (Sandhu et al., 2011).

The purpose of this study was to assess whether ozone treatment could improve the properties of soft wheat flour for cake-making and thus offer a more environmentally acceptable alternative to chlorination. Following this, a second aim was to try to throw light on the mechanism by which ozone modified flour (and thus cake) properties. Two variables that were studied were the effects of flour lipid removal and the changes in protein measured by Size-exclusion High Performance Liquid Chromatography (SE-HPLC).

\section{Materials and methods}

\subsection{Materials}

Unchlorinated and chlorinated flours from the same soft wheat were provided by ConAgra Foods (Alton, IL). All vegetable shortening was donated by ADM packaged oils (Decatur, IL). Non fat dried milk was provided by Ryt-way Industries 
Inc. (Northfield, MW). Double acting baking powder was obtained from Clabber Girl (Terre Haute, IN). Fine granulated sugar was obtained from Domino Foods Inc. (Baltimore, MD).

\subsection{Methods}

\subsubsection{Analytical determination}

Protein contents of flour samples were analysed by the combustion method using a LECO FP2000 Nitrogen/Protein Analyzer. A factor of 5.7 was used to convert nitrogen $(\mathrm{N})$ to protein. Moisture content was determined according to AACC method 44-15A (AACC, 2000)

\subsubsection{Ozone production}

Ozone gas was generated by a pilot scale ozone generator (Clear Water Tech. Inc., San Luis Obispo, CA). The rate of ozone production was measured by an iodometric method for determination of ozone in a process gas. Ozone gas was passed through three sets of glass wash bottles containing $250 \mathrm{ml}$ distilled water as a detector for ozone transfer and reaction, $4 \mathrm{~g}$ of potassium iodide, and $15 \mathrm{ml}$ of $0.3 \mathrm{M}$ sulphuric acid and then the solution was titrated against $0.01 \mathrm{~N}$ sodium thiosulphate containing starch indicator solution. Ozone concentration was calculated from $\mathrm{ml}$ of sodium thiosulphate usage.

\subsubsection{Production of ozone treated flour}

The ozone gas was tumbled in the chlorination box filled with $5 \mathrm{lb}(2.27 \mathrm{~kg})$ of non chlorinated soft wheat flour. The ozone was introduced at the rate of $0.06 \mathrm{~L} / \mathrm{min}$ for times of 10, 20, 30, 36, and $40 \mathrm{~min}$. A tube from the box allowed gas to be expelled to the open air, preventing build up of gas inside the room. Ozone 
production measured by the iodometric method increased linearly with time and was given by the equation:

$$
\text { conc }=0.08 \mathrm{t}-0.45
$$

Where conc is the concentration of ozone $(\mathrm{mg} / \mathrm{kg}$ flour) and $\mathrm{t}$ is the time in min.

\subsubsection{Flour properties}

The $\mathrm{pH}$ of flour samples was measured by AACC method 02-50 (AACC, 2000). Ten grams of flour were added to $100 \mathrm{ml}$ distilled water. The flour suspension was placed on a stirring plate and stirred for $15 \mathrm{~min}$. It was then stood for $10 \mathrm{~min}$ and the supernatant decanted and used for $\mathrm{pH}$ measurement.

Flour colour was measured with a Minolta colorimeter (Minolta Corp., Ramsey, NJ) and the $\mathrm{L}^{*}, \mathrm{a}^{*}$ and $\mathrm{b}^{*}$ values were recorded.

\subsubsection{Lipid extraction}

Unchlorinated flour was extracted with chloroform according to MacRitchie and Gras (1973). Three extractions were performed using $200 \mathrm{~g}$ of flour and $400 \mathrm{ml}$ of chloroform for each successive extraction. The flour was filtered through a Whatman No. 1 filter paper and placed in a fume hood for 12 hours at room temperature to allow evaporation of the chloroform.

\subsubsection{Size Exclusion High Performance Liquid Chromatography (SE-HPLC)}

SE-HPLC was performed using s Hewlett Packard 1100 system with a UV detector set at $214 \mathrm{~nm}$. A BioSep-Sec-S4000 column 300 x $7.8 \mathrm{~mm}$ (Phenomenex, Torrance, CA) was used for protein fractionation. The elution solvent was deionized water and acetonitrile (1:1), both containing $0.05 \%$ trifluoroacetic acid (TFA) with a flow rate of $0.5 \mathrm{ml} / \mathrm{min}$.

Procedures were based on those of Gupta et al. (1993). For total protein determination, $10 \mathrm{mg}$ of flour was suspended in $1 \mathrm{ml}$ of $0.05 \%$ sodium dodecyl 
sulphate (SDS) and $0.05 \mathrm{mM}$ dibasic sodium phosphate buffer, $\mathrm{pH}$ 6.9. Samples were vortexed for $5 \mathrm{~min}$. and sonicated at an output of 6 watts for $15 \mathrm{sec}$. Samples were centrifuged at $12000 \mathrm{x}$ g for $20 \mathrm{~min}$., the supernatants were filtered and transferred to HPLC glass vials. For unextractable protein, the same extraction procedure was followed without sonication. After removal of the supernatant (containing extractable polymeric protein), $1 \mathrm{ml}$ of SDS-buffer solution was added to the residue and the dispersion sonicated for $25 \mathrm{sec}$ to give the solution for measurement of unextractable polymeric protein (UPP). Areas under the chromatograms were integrated in three parts. The first peak contained polymeric proteins (mainly glutenins). The second peak contained mostly gliadins and the third peak was albumins and globulins. The proportion (\%) of total polymeric protein (TPP) was calculated as (peak 1 area/total area) $x 100$. The percentage of unextractable polymeric protein (UPP) in the total polymeric protein was calculated as peak 1 area (unextractable)/peak 1 area (total). Peak 1 area (total) is the sum of peak 1(extractable) and peak 1(unextractable). 2.2.7. Viscosity of cake batter

Cake batter viscosity was determined according to Kim and Walker (1992) using a Brookfield Synchro-lectric viscometer model LVt (VS4) (Brookfield Engineering Laboratories, Inc., Stoughton, MA). Spindle number 4 was used and the viscosity measured in centipoises. These measurements were done on a flour that had been tumbled in a metal box as part of a study of the effects of temperature and ozonation time on flour properties (Chittrakorn, 2008)

\subsubsection{Baking test}

All cakes were baked according to AACC method 10-90 (AACC 2000). The optimum level of water and double acting baking powder were first determined by adjusting these variables in order to obtain a maximum cake volume, consistent with a 
satisfactory texture. Three different levels of distilled water, 250, 270, and $290 \mathrm{ml}$ were tested and the optimum water level was determined to be $270 \mathrm{ml}$ of water which gave a highest cake volume. All dry ingredients were sifted and transferred to the mixing bowl. Shortening and $60 \%$ of distilled water were added. The ingredients were mixed at a low speed for $30 \mathrm{sec}$. using a Hobart mixer, scraped down and mixed at medium speed for $4 \mathrm{~min}$. One half of the remaining water $(20 \%)$ was added to the batter and mixed at low speed for 30 sec. and then at medium speed for $2 \mathrm{~min}$. The remaining water $(20 \%)$ was added to the batter and mixed at low speed for $30 \mathrm{sec}$. and then at medium speed for 2 min. $425 \mathrm{~g}$ of cake batter was transferred into each of two greased pans and baked with electrical oven at 190C (375F) for $22 \mathrm{~min}$.

\subsubsection{Cake quality}

Volumes of cakes were measured by a plastic measurement template according to AACC method 10-91 (AACC 2000) and volume index was calculated based on the following equation; Volume index $=\mathrm{B}+\mathrm{C}+\mathrm{D}$ Where $\mathrm{B}, \mathrm{C}$, and $\mathrm{D}$ is the height of cake at vertical lines of plastic template designated for cake volume calculations.

A texture analyzer (TA.XT2, Stable Micro Systems Ltd) was used to measure hardness, springiness and cohesiveness of cakes. Texture profile analysis (TPA) was performed using a 1 inch $(2.25 \mathrm{~cm})$ diameter cylinder probe. The TPA test setting was as follows: pretest, test and post test speeds were $2.0 \mathrm{~mm} / \mathrm{sec}$, a distance of $10 \mathrm{~mm}$ was used to compress the sample, and the time between each stroke was $3.0 \mathrm{sec}$. For sample preparation, each cake was cut into 4 pieces with dimensions of 2 inch $\times 2$ inch $x 1$ inch. Cakes were sliced with an electric knife and central slices of $15 \mathrm{~mm}$ thickness were used. Gas cell structure of cakes was measured with an image analysis instrument (C-Cell imaging system, Calibre Control International Ltd., UK). Image 
analysis parameters, including slice brightness and number of cells, were recorded The colour of the cake crumb was measured by a Minolta colorimeter and $L^{*}, a^{*}$ and $b^{*}$ values were recorded.

\subsubsection{Statistical analysis}

The completed randomized design was used in all experiments. Except cake baking test that used randomized complete block design. Data were analysed using SAS (version 9.1, SAS Institute Inc., Cary, NC). Analysis of results was performed using analysis of variance (ANOVA). Differences among means were compared using least significance difference $(\alpha=0.05)$. All analyses were performed in triplicate.

\section{Results}

\subsection{Flour properties}

The flour protein and moisture contents were $7.5 \%$ and $12.5 \%$ (unchlorinated) and $7.5 \%$ and $12.4 \%$ (chlorinated). The $\mathrm{pH}$ and colour of flours treated with chlorine and ozone are summarized in Table 1 . The $\mathrm{pH}$ decreased with increasing time of ozone treatment but the decrease was less than for chlorine, suggesting that the oxidation mechanism for chlorine and ozone may be different. A decreasing $\mathrm{pH}$ of ozone treated flour might occur from the oxidation of flour components such as carbohydrate, amino acid, and unsaturated fatty acid compounds by ozone, leading to the formation of acid products (Langlais et al., 1991). The lightness $\left(L^{*}\right)$ of chlorinated and ozonated flours were not significantly different from the untreated flour. Yellowness for chlorinated and ozonated flour was significantly lower than that 
of untreated flour and redness was also slightly lower $(P<0.05)$. The results indicate that ozone has an ability to oxidize the yellow pigments in wheat flour such as the carotenoids. Lutein, the primary carotenoid pigment in wheat flour, contains conjugated double bonds that may readily be oxidized by ozone (Sandhu et al., 2011).

\subsection{Cake batters}

Viscosity of cake batters from flours that have been ozonated for different times is shown in Fig. 1. The viscosity is seen to increase significantly with increase of flour ozonation time. The specific gravity of cake batters decreased from 1.05 to 0.8 when the ozonation time increased from $5 \mathrm{~min}$. to $25 \mathrm{~min}$. (results not shown). The increase of viscosity and decrease of specific gravity at long treatment time indicated large numbers of gas cells incorporated into the cake batter. During mixing, air incorporates into cake batter and the viscosity of batter increases. A high batter viscosity prevents air bubbles from rising to the top, resulting in increase of batter stability at room temperature (Hoseney, 1994; Payne, 1995). Batter specific gravity related to the volume, tenderness, and final grain and texture of cakes (Pyler, 1988).

\subsection{Cake volume and gas cell structure}

The volumes of cakes treated with ozone for 10, 20, 30, 36 and $40 \mathrm{~min}$. are plotted in Fig. 2. Volumes increased up to $36 \mathrm{~min}$., thereafter decreasing. In order to pinpoint the optimum time more closely, the experiment was repeated with time intervals of $2 \mathrm{~min}$. between 32 and $38 \mathrm{~min}$. (results not shown). The optimum time (i.e. the time corresponding to the highest volume) was found to be $36 \mathrm{~min}$. This confirmed the optimum time reported by Earls (2003). Cross sections of cakes from flours treated with ozone for $10 \mathrm{~min}$. and $36 \mathrm{~min}$. are compared with those from 
untreated and chlorinated flours in Fig. 3. Slice brightness and number of cells of cakes from the optimally ozonated flour were comparable to the same parameters for cakes from chlorinated flour (see also Chittrakorn, 2008).

\subsection{Textural properties of cakes}

Textural properties of cakes are summarized in Table 2. Cakes from ozone treated flours were softer than cakes from chlorinated and control (unchlorinated) flours. Increase of ozonation time decreased the hardness of cakes. In agreement with Donelson et al. (2000), cakes from chlorinated, as well as ozonated, flours had higher springiness than cake from unchlorinated flour, although the differences were not significant.

\subsection{Lipid extraction}

Effects on cake quality of flour lipid extraction are shown in Fig. 3. Lipid extraction of untreated flour gave cakes with little expansion and prior chlorination or ozonation of the flours did not correct this and, in fact, appeared to be more detrimental. Spies and Kirleis et al. (1978) stated that free lipids are required for cake structure formation. Cake baked with hexane extracted flour had poor grain quality and a flat contour.

\subsection{SE-HPLC of proteins}

Compositional data for proteins from untreated, chlorinated and ozonated (10 min. and 36 min.) flours, measured by SE-HPLC, are summarized in Table 3. As would be expected, there were no differences in proportions of the main protein groups, as shown by the constancy of the total polymeric protein (TPP) but ozonation caused an increase in the percentage of unextractable polymeric protein (UPP). The UPP is positively related to the molecular weight distribution (MWD) of the polymeric protein. The increase in UPP resulting from ozonation was consistent with 
an increased dough strength shown by mixograms (results not shown). The UPP indicated large-sized polymeric protein (above a certain size). Oxidizing agents such as potassium bromate and potassium iodate can oxidized SH groups of high and low molecular weight glutenin subunits and increase in average molecular size was detected (Veraverbeke et al., $2000 \mathrm{a}, \mathrm{b}$ ). This result indicated that ozone might oxidize $\mathrm{SH}$ groups of cysteine residues in protein molecules leading to the formation of intermolecular SS bonds, resulting in increasing the molecular weight of polymeric protein.

\section{Discussion}

Ozonation of flour gave enhanced volume and gas cell structure of high ratio cakes similar to that of chlorinated flour. Thus, on that basis, ozonation appears to be a viable alternative to chlorination and is more environmentally acceptable. For the conditions used, there is an optimum treatment time for flour. Cake volume increases with increasing time of ozonation up to a maximum (36 min. under the conditions used), thereafter decreasing.

Although the effects of ozonation on batter viscosity and cake quality are similar to those of chlorination, there are indications that the mechanism may not be exactly the same. The lowering of $\mathrm{pH}$ by ozonation is not so marked as for chlorination. In addition, the SE-HPLC data shows that ozonation causes an increase in the MWD of the polymeric protein whereas chlorination does not. The polymerization may occur through oxidation of sulfhydryl groups to form disulfide linkages between glutenin molecules. The maximum in cake volume with increasing ozonation of the flour suggests that there is an optimum MWD above which further polymerization is detrimental. 
Lipids appear to play an important role in cake quality as has been reported in a number of studies (Seguchi and Matsuki, 1977; Kissell et al, 1979). Their removal gave low cake volume which was not improved by chlorination or ozonation. Results of Donelson et al (1984), using fraction interchange suggested that improvement in cake volume by chlorine treatment of flour was related to its effect on lipids and this may also be the case for ozone. Lipids, due to their surface active properties are expected to play a role in foam formation and stability.

One problem encountered with ozonation was that flours acquire an unpleasant odour. This will be discussed in a subsequent publication.

\section{References}

AACC, 2000. In: Approved Methods of the AACC, tenth ed. American Association of Cereal Chemists, St. Paul, MN.

Chittrakorn, S. 2008. Use of ozone as an alternative to chlorine for treatment of soft wheat flours. Ph.D Thesis, Kansas State University.

Clements, R.L., Donelson, J.R. (1982). Role of free flour lipids in batter expansion in layer cakes I. Effects of "aging”. Cereal Chemistry 59: 125-128.

Desvignes, C., Chaurand, M., Dubois, M., Sadoudi, A., Abecassis, J., Lullien-Pellerin, V. 2008. Changes in common wheat grain milling behaviour and tissue mechanical properties following ozone treatment. Journal of Cereal Science 47:245-251.

Donelson, J.R., Gaines, C.S., Finney, P.L. 2000. Baking formula innovation to eliminate chlorine treatment of cake flour. Cereal Chemistry 77:53-57.

Donelson, J.R., Yamazaki, W.T., Kissell, L.T. 1984. Functionality in white layer cake of lipids from untreated and chlorinated patent flours. II. Flour fraction interchange studies. Cereal Chemistry 61:88-91. 
Earls, D. 2003. Alternative to chlorination of cake flour. Ph.D.Thesis, Kansas State University.

Gough, B.M., Greenwood, C.T., Whitehouse, M.E. 1978. The role and function of chlorine in the preparation of high ratio cake flour. Critical Reviews in Food Science and Nutrition 10:91-113.

Gupta, R.B., Khan, K., MacRitchie, F. 1993. Biochemical basis of flour properties in bread wheats. I. Effects of variation in the quality and size distribution of polymeric protein. Journal of Cereal Science 18:23-41.

Hoseney, R.C. 1994. Principles of Cereal Science and Technology. American Association of Cereal Chemists, Inc. St. Paul, Minnesota, USA.

Kissell, L.,T., Yamazaki, W.T. 1979. Cake-baking dynamics: Relation of flour chlorination and rate to batter expansion and layer volume. Cereal Chemistry $56: 324-327$

Kim, C.S.,Walker, C.E. 1992. Interaction between starches, sugars, and emulsifiers in high ratio cake model systems. Cereal Chemistry 69:206-212.

Langlias, B., Reckhow, D.A., Brink, D.R. 1991. Ozone in Water Treatment Application and Engineering. Lewis Publishers, Inc. Michigan, USA.

MacRitchie, F., Gras, P.W. 1973. The role of flour lipids in baking. Cereal Chemistry 50:292-302.

Payne, J. 1995. Baking Science I Laboratory manual. Department of Grain Science and Industry, Kansas State University, Manhattan, Kansas, USA.

Pyler, E.J. 1988. Baking Science and Technology. Sosland Publishing company., Kansas City, Missouri, USA.

Russo, J.V.B., Doe, G.A.F. 1970. Heat treatment of flour as an alternative to chlorination. Journal of Food Technology 5:363-374. 
Sandhu, H., Manthey, F.A., Simsek, S., Ohm, J. 2011. Comparison between potassium bromate and ozone as flour oxidants in breadmaking. Cereal Chemistry 88:103-108.

Sollars, W.F., Rubenthaler, G.L. 1971. Performance of wheat and other starches in reconstituted flours. Cereal Chemistry 48:397- 410.

Spies, R.D., Kirleis, A.W. 1978. Effect of free flour lipids on cake-baking potential. Cereal Chemistry. 55:699-704.

Thomasson, C.A., Miller, R.A., Hoseney, R.C. 1995. Replacement of chlorine treatment for cake flour. Cereal Chemistry 72:616-620.

Tiwari, B.K., Brennan, C.S., Curran, T., Gallagher, E., Cullen, P.J., O’Donnell, C.P. 2001. Application of ozone in grain processing. Journal of Cereal Science $51: 248-255$.

Veraverbeke, W.S., Larroque, O.R., Bekes, F., and Delcour, J.A. 2000a. In vitro polymerization of wheat glutenin subunits with inorganic oxidizing agents. I. Comparison of single-step and stepwise oxidations of high molecular weight glutenin subunits. Cereal Chemistry 77: 582-588.

Veraverbeke, W.S., Larroque, O.R., Bekes, F., and Delcour, J.A. 2000b. In vitro polymerization of wheat glutenin subunits with inorganic oxidizing agents. II. Stepwise oxidation of low molecular weight glutenin subunits and a mixture of high and low molecular weight glutenin subunits. Cereal Chemistry 77:589594.

Violleau, F., Pernot, A.-G., Surel, O. 2012. Effect of Oxygreen ${ }^{\circledR}$ wheat ozonation process on bread dough quality and protein solubility. Journal of Cereal Science 55:392-396. 
Table 1

$\mathrm{pH}$ and colour of untreated soft wheat flour, chlorinated flour and flour treated with ozone at $10 \mathrm{~min}$ and $36 \mathrm{~min}$.

\begin{tabular}{lllll}
\hline \multirow{2}{*}{ Flours } & $\mathrm{pH}$ & \multicolumn{4}{l}{ Colour of flour ${ }^{\mathrm{a}}$} \\
\cline { 3 - 5 } & & $L^{*}$ & $a^{*}$ & $b^{*}$ \\
\hline Control (unchlorinated) & 6.07 & $91.26 \mathrm{a}$ & $-2.59 \mathrm{c}$ & $8.10 \mathrm{a}$ \\
Chlorinated flour & 4.49 & $91.36 \mathrm{a}$ & $-1.78 \mathrm{a}$ & $5.03 \mathrm{~b}$ \\
10 min ozonated & 5.96 & $92.24 \mathrm{a}$ & $-1.94 \mathrm{~b}$ & $5.09 \mathrm{~b}$ \\
36 min ozonated & 5.66 & $91.80 \mathrm{a}$ & $-1.88 \mathrm{ab}$ & $5.26 \mathrm{~b}$ \\
\hline${ }^{\mathrm{a}}$ Means with the same letter within columns are not significantly different \\
$(P>0.05)$.
\end{tabular}

Table 2

Textural properties of cakes measured by TA XT2.

\begin{tabular}{llll}
\hline Cakes & \multicolumn{2}{l}{ Textural properties ${ }^{\mathrm{a}}$} \\
\cline { 2 - 4 } & $\begin{array}{l}\text { Hardness } \\
(\mathrm{g})\end{array}$ & $\begin{array}{l}\text { Springiness } \\
(\%)\end{array}$ & $\begin{array}{l}\text { Cohesiveness } \\
(\%)\end{array}$ \\
\hline Control (unchlorinated) & $544.3 \mathrm{a}$ & $89.6 \mathrm{a}$ & $69.6 \mathrm{a}$ \\
Chlorinated flour & $602.7 \mathrm{a}$ & $92.3 \mathrm{a}$ & $75.0 \mathrm{a}$ \\
10 min ozonated & $461.1 \mathrm{~b}$ & $91.3 \mathrm{a}$ & $72.7 \mathrm{a}$ \\
36 min ozonated & $446.0 \mathrm{~b}$ & $94.1 \mathrm{a}$ & $73.2 \mathrm{a}$ \\
\hline
\end{tabular}

${ }^{a}$ Means with the same letter within columns are not significantly different $(P>0.05)$.

Table 3

SE-HPLC relative composition (percentage) of total polymeric protein (TPP) and unextractable polymeric protein (UPP) in unchlorinated, chlorinated and ozonated flours.

\begin{tabular}{lll}
\hline Flours & TPP $^{\mathrm{a}}$ & UPP $^{\mathrm{a}}$ \\
\hline Control (unchlorinated) & $38.26 \pm 0.28$ & $37.32 \pm 1.43$ \\
Chlorinated flour & $38.55 \pm 0.33$ & $37.83 \pm 1.01$ \\
10 min ozonated & $38.80 \pm 0.28$ & $43.43 \pm 1.39$ \\
36 min ozonated & $38.99 \pm 0.59$ & $45.70 \pm 2.00$ \\
\hline
\end{tabular}

UPP $=$ unextractable polymeric protein.

a Values represent mean \pm standard deviation; TPP $=$ total polymeric protein. 


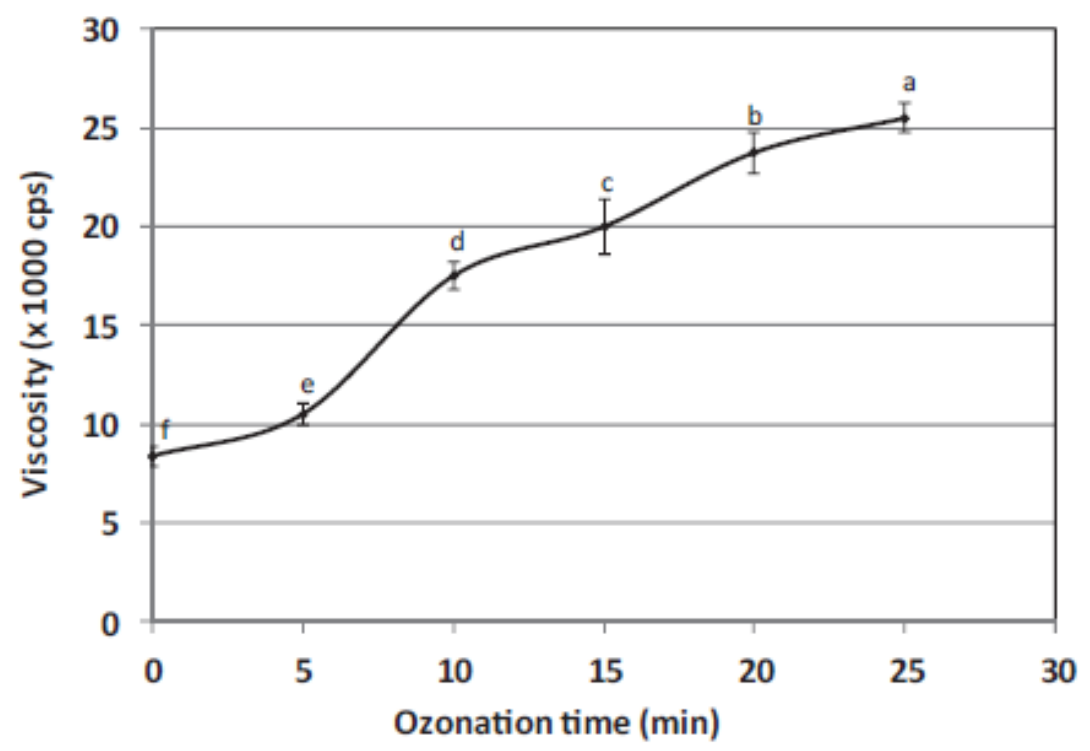

Fig. 1. Viscosity of cake batters as a function of flour ozonation time

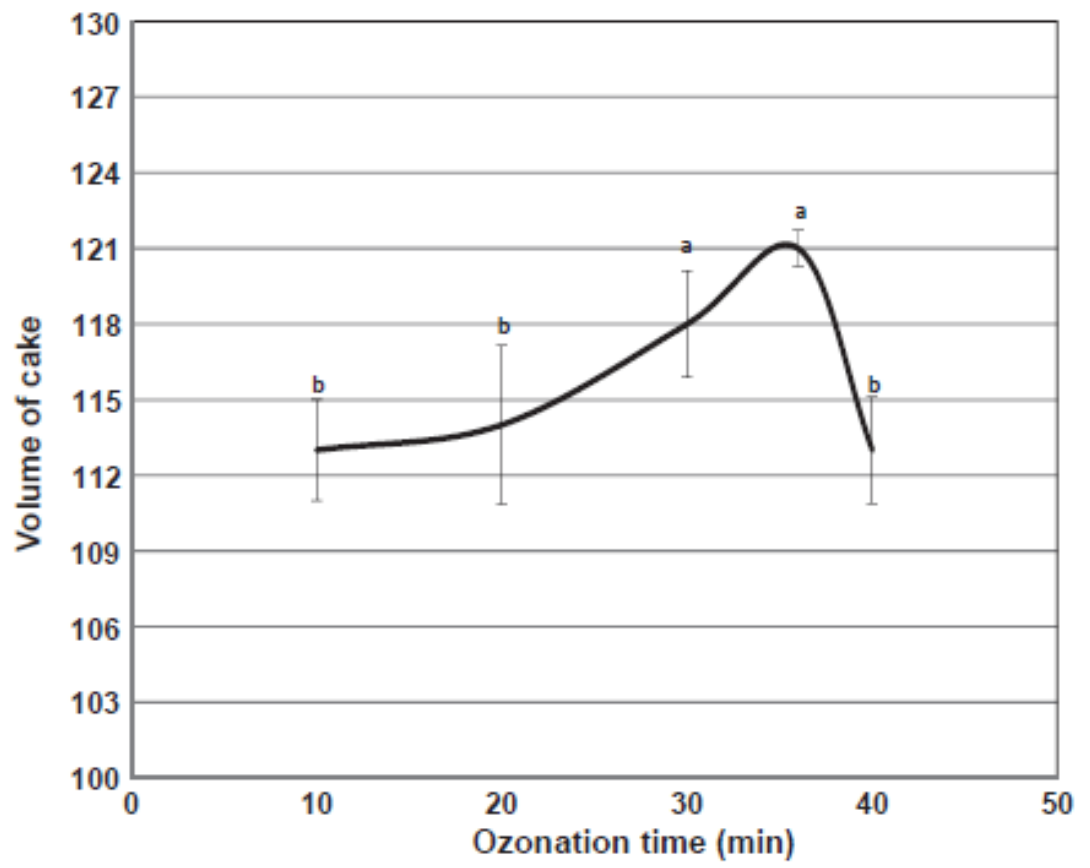

Fig. 2. Cake volume vs. time of flour ozonation 


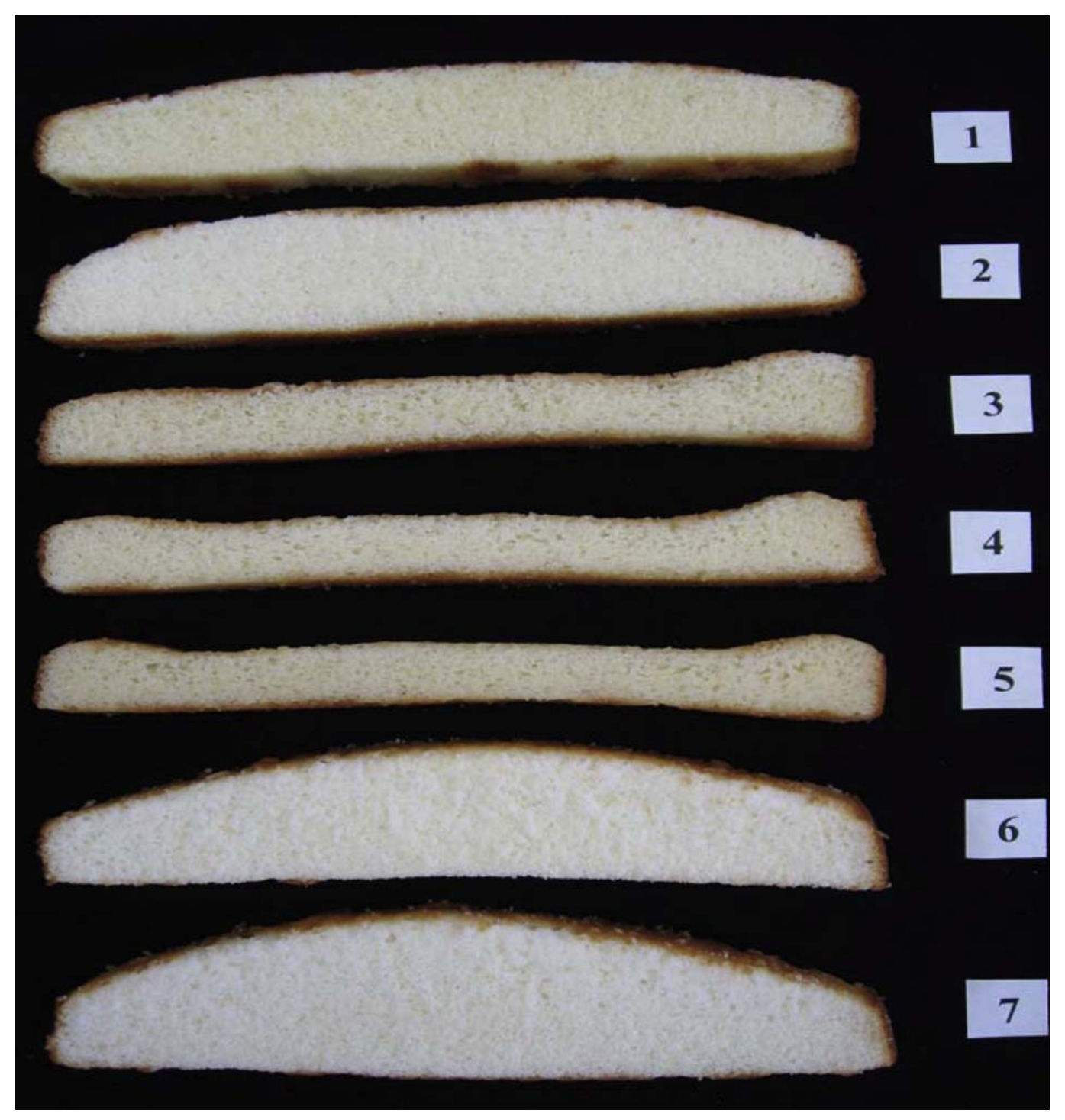

Fig. 3. Cross-sections of cakes made from flours with different treatments. 1. Control (unchlorinated) 2. Chlorinated 3. Control with lipid extraction 4. Control with lipid extraction and ozonation for $10 \mathrm{~min}$ 5. Control with lipid extraction and ozonation for $36 \min 6$. Ozonation for $10 \min 7$. Ozonation for $36 \mathrm{~min}$ 